\title{
Extracorporeal lung support for patients who had severe respiratory failure secondary to influenza A (H1N1) 2009 infection in Canada
}

\section{Assistance pulmonaire extracorporelle pour les patients ayant souffert d'insuffisance respiratoire grave par suite d'une infection à la grippe A (H1N1) 2009 au Canada}

\author{
Darren H. Freed, MD, PhD - Dietrich Henzler, MD - Chris W. White, MD • \\ Robert Fowler, MD · Ryan Zarychanski, MD · Jamie Hutchison, MD · \\ Rakesh C. Arora, MD, PhD • Rizwan A. Manji, MD, PhD · Jean-Francois Legare, MD • \\ Tanya Drews, MD $\cdot$ Stasa Veroukis, MD • Murray Kesselman, MD • \\ Anne-Marie Guerguerian, MD $\cdot$ Anand Kumar, MD $\cdot$ the Canadian Critical Care Trials Group
}

Received: 22 October 2009/Accepted: 10 December 2009/Published online: 16 January 2010

(c) Canadian Anesthesiologists' Society 2010

\begin{abstract}
Background From March to July 2009, influenza A (H1N1) 2009 (H1N1-2009) virus emerged as a major cause of respiratory failure that required mechanical ventilation. A small proportion of patients who had this condition developed severe respiratory failure that was unresponsive to conventional therapeutic interventions. In this report, we describe characteristics, treatment, and outcomes of critically ill patients in Canada who had H1N1-2009 infection and were treated with extracorporeal lung support (ECLS).
\end{abstract}

This article is accompanied by an editorial. Please see Can J Anesth 2010; 57(3).

\section{H. Freed, MD, PhD ( $₫)$}

Surgical Heart Failure Program, Cardiac Sciences Program, St. Boniface General Hospital, CR3030 Asper Clinical Research Building, 369 Tache Ave, Winnipeg, Manitoba R2H 2A6,

Canada

e-mail: dfreed@sbgh.mb.ca

C. W. White, MD · R. Zarychanski, MD .

R. C. Arora, MD, PhD - R. A. Manji, MD, PhD .

T. Drews, MD - S. Veroukis, MD - M. Kesselman, MD .

A. Kumar, MD

University of Manitoba, Winnipeg, Manitoba, Canada

D. Henzler, MD · J.-F. Legare, MD

Dalhousie University, Halifax, Nova Scotia, Canada

R. Fowler, MD · J. Hutchison, MD · A.-M. Guerguerian, MD

University of Toronto, Toronto, Ontario, Canada
Methods We report the findings of a case series of six patients supported with ECLS who were included in a cohort study of critically ill patients with confirmed HIN12009 infection. The patients were treated in Canadian adult and pediatric intensive care units (ICUs) from April 16, 2009 to August 12, 2009. We describe the nested sample treated with ECLS and compare it with the larger sample.

Results During the study period, 168 patients in Canada were admitted to ICUs for severe respiratory failure due to confirmed H1N1-2009 infection. Due to profound hypoxemia unresponsive to conventional therapeutic interventions, six (3.6\%) of these patients were treated with ECLS in four ICUs. Four patients were treated with veno-venous pump-driven extracorporeal membrane oxygenation ( $v v-E C M O)$, and two patients were treated with pumpless lung assist (NovaLung iLA). The mean duration of support was 15 days. Four of the six patients survived (66.6\%), one of the surviving patients was supported with iLA and the other three surviving patients were supported with ECMO. The two deaths were due to multiorgan failure, which occurred while the patients were on ECLS.

Interpretation Extracorporeal lung support may be an effective treatment for patients who have H1N1-2009 infection and refractory hypoxemia. Survival of these patients treated with ECLS is similar to that reported for patients who have acute respiratory distress syndrome of other etiologies and are treated with ECMO. 


\section{Résumé}

Contexte Entre mars et juillet 2009, le virus de la grippe A (H1N1) 2009 (H1N1-2009) est apparu comme une cause majeure d'insuffisance respiratoire nécessitant une ventilation mécanique. Une petite proportion des patients souffrant de cette grippe ont manifesté une insuffisance respiratoire grave qui n'a pu être traitée efficacement avec les interventions thérapeutiques traditionnelles. Dans ce compte-rendu, nous décrivons les caractéristiques, le traitement et les devenirs de patients gravement malades au Canada qui avaient été infectés par le virus H1N1-2009 et qui ont été traités avec une assistance pulmonaire extracorporelle (APEC).

Méthode Nous rapportons les résultats d'une série de cas de six patients bénéficiant d'une APEC qui ont pris part à une étude de cohorte portant sur les patients gravement malades et chez qui l'infection au H1N1-2009 avait été confirmée. Les patients ont été traités dans des unités de soins intensifs (USI) pour patients adultes et pédiatriques entre le 16 avril 2009 et le 12 août 2009. Nous décrivons l'échantillon à plusieurs degrés traité avec une APEC et le comparons à l'échantillon plus large.

Résultats Pendant la période d'étude, 168 patients ont été admis aux soins intensifs au Canada en raison d'insuffisance respiratoire grave provoquée par une infection au H1N1-2009 confirmée. En raison d'une hypoxémie profonde ne répondant pas aux interventions thérapeutiques traditionnelles, six (3,6\%) de ces patients ont été traités par APEC dans quatre USI. Quatre patients ont été traités par oxygénation extracorporelle veino-veineuse par pompe (vv-ECMO), et deux patients ont été traités par assistance pulmonaire sans pompe (NovaLung iLA). La durée moyenne d'assistance était de 15 jours. Quatre de ces six patients ont survécu $(66,6 \%)$, l'un des patients survivants a été traité par iLA et les trois autres par ECMO. Les deux décès ont été causés par une défaillance multisystémique alors que les patients étaient traités par APEC.

Interprétation L'assistance pulmonaire extracorporelle pourrait constituer un traitement efficace pour les patients infectés par le virus H1N1-2009 et souffrant d'hypoxémie réfractaire. La survie des patients traités par APEC est semblable à celle rapportée dans le cas de patients souffrant de syndrome de détresse respiratoire aigué provoqué par d'autres étiologies et traités par APEC.

An outbreak of respiratory illness that began in Mexico in late March 2009 has subsequently been attributed to a novel swine-origin influenza A (H1N1) virus (H1N12009). ${ }^{1}$ As of September 6, 2009, over 277,600 laboratoryconfirmed cases were reported in over 100 countries. $^{2}$ In
Canada, since the first laboratory-confirmed cases of H1N1-2009 were identified in a group of students from Nova Scotia who had travelled to Mexico in early April $200^{3,9}$ there have been over 10,000 laboratory-confirmed cases of H1N1-2009, including over 1,000 patients who were hospitalized and 74 patients who have died. ${ }^{4,5}$ Canada has the highest rate of confirmed cases of H1N1-2009 with a disproportionate number of young patients, females, Aboriginals, and patients who do not have major comorbidities affected. ${ }^{6}$

Most patients diagnosed with H1N1-2009 virus have had a self-limited respiratory illness, have exhibited symptoms similar to those of seasonal influenza, including cough, fever, sore throat, malaise and headache, and have recovered without complication. ${ }^{7}$ However, approximately $5-9 \%$ of these patients in the United States ${ }^{8,9}$ and $11 \%$ in Canada $^{5}$ required hospitalization. Further, 20-36\% of hospitalized patients were admitted to the intensive care unit (ICU). Over $80 \%$ of patients admitted to the ICU required mechanical ventilation and $17-40 \%$ died. ${ }^{10}$ Infection with H1N1-2009 can result in rapidly progressive respiratory failure, acute respiratory distress syndrome (ARDS), and death. ${ }^{11}$

Mechanical ventilation is usually necessary to support gas exchange in patients with ARDS, although mechanical ventilation itself can be associated with lung injury. Despite attempts to optimize ventilator settings, ${ }^{12}$ hypoxemia or hypercapnia refractory to conventional mechanical ventilation may persist in a small subset of patients, and these patients may be treated with extracorporeal lung support (ECLS). Extracorporeal membrane oxygenation (ECMO) is a technology of facilitating gas exchange over a microporous membrane by pumping the patient's blood through an extracorporeal circuit. Recently, a pumpless circuit was developed (interventional lung assist, iLA) that is specifically effective for carbon dioxide removal. ${ }^{13}$ So far, ECLS has been provided in specialized centres as an alternative therapy for patients who have not responded to conventional treatment. This report describes the epidemiologic characteristics, clinical features, treatment, and outcomes of a multicentre cohort of adult and pediatric Canadian ICU patients who had severe respiratory failure due to H1N1-2009 virus and were treated with ECLS.

\section{Methods}

In response to an outbreak of H1N1-2009 infection in Mexico, members of the Canadian Critical Care Trials Group (CCCTG) developed a case report form and designed a multicentre observational study of critically ill patients who were infected with this virus. Data were collected retrospectively or prospectively on all patients 
who had H1N1-2009-related critical illness from April 2009 to August 2009. On April 30, 2009, research ethics board approval was granted by Sunnybrook Health Sciences Centre as the central coordinating centre and by each participating local research ethics board. The need for a priori informed consent was waived due to the noninterventional study design. The results of the entire cohort were recently published. ${ }^{10}$ An additional form was developed and disseminated to allow collection of ECLSspecific data. Herein we present a detailed examination of patients who were supported with ECLS. The use and indications for ECLS were left to the treating physician. For study purposes, indications for ECLS were grouped into broad categories, i.e., hypoxemia, hypercarbia, impossible to ventilate, other, and the worst physiologic data preceding initiation of ECLS were recorded.

Eligible patients included all adult and pediatric critically ill patients, as previously defined, ${ }^{10}$ who were admitted to participating ICUs in Canada and had suspected, probable, or confirmed H1N1-2009 infection. ${ }^{14,15}$ Eligibility criteria were confirmed and data were recorded by research coordinators or site investigators at each centre. Severity of illness was assessed in adults and children using the Acute Physiology and Chronic Health Evaluation (APACHE) II and the Pediatric Risk of Mortality (PRISM) III score,${ }^{16,17}$ respectively. We recorded co-morbidities and a priori defined major co-morbidities as the presence of one or more of the following chronic medical conditions: congestive heart failure; cerebrovascular, neoplastic, chronic liver, or renal diseases; and use of immunosuppressant medications. ${ }^{18}$ Data were submitted to the coordinating centre and checked for errors by manual inspection and electronic range limits. Descriptive statistics included frequency analysis (percentages) for categorical variables and means (standard deviation $[\mathrm{SD}]$ ) or medians (interquartile range $[\mathrm{IQR}]$ ) for continuous variables. Analyses were conducted using $\mathrm{SAS}^{\circledR}$ version 9.1 (SAS Institute, Cary, NC, USA).

\section{Results}

Characteristics of study patients

As previously reported, ${ }^{10}$ from April 2009 to August 2009, 168 critically ill patients were admitted to 34 study ICUs in Canada due to confirmed H1N1-2009 infection. The average age was $32 \mathrm{yr}$ and $67.3 \%$ were female (Table 1). Six of these patients were unresponsive to conventional therapy and were treated with ECLS. Although there were no standard inclusion/exclusion criteria, all ECLS programs were heavily influenced by the criteria outlined in the Conventional Ventilation or ECMO for Severe Adult
Respiratory Failure (CESAR) trial, ${ }^{19}$ with hypoxemia (P/F ratio $<100$ on $\mathrm{F}_{\mathrm{I}} \mathrm{O}_{2}=1.0$ ) being the primary indication for ECLS in our series. These patients were profoundly hypoxemic (mean $\mathrm{PaO}_{2} / \mathrm{F}_{1} \mathrm{O}_{2} 61 \mathrm{mmHg}$ ) and hypercapneic (mean $\mathrm{PaCO}_{2} 70 \mathrm{mmHg}$ ) one hour before the start of ECLS. Three patients were treated with high frequency oscillation ventilation (HFOV); all received inhaled nitric oxide during their ICU stay, and two had hemodynamic instability requiring intravenous inotropic medication. Two patients had a cardiac arrest before initiation of ECLS. Table 2 outlines the ECLS patient characteristics.

\section{Conduct of ECLS}

Transesophageal or transthoracic echocardiography was performed in all patients who were treated with ECLS. No intracardiac shunts or valvular lesions were discovered. Left ventricular function was normal in all patients; one patient who had previous Tetralogy of Fallot repair had mildly impaired right ventricular function. Right ventricular systolic pressure was normal in three patients, mildly elevated in one patient, and significantly elevated in the remaining two patients. All patients were cannulated peripherally, and all circuits were heparin-coated. For three patients who were treated with vv-ECMO, the circuit utilized a Rotaflow pump and a Quadrox D oxygenator (Maquet-Dynamed, Markham, ON, Canada). For the fourth patient, the circuit consisted of a Biomedicus (Medtronic Inc, Minneapolis, MN, USA) and Medos 2400LT oxygenator. Cannulation for ECMO consisted of drainage from a femoral vein with return to the contralateral femoral vein via a long single stage cannula advanced to the level of the inferior vena cava/right atrial junction. To improve blood flow, three patients required insertion of a third cannula in the right internal jugular vein. Two patients were supported with the Interventional Lung Assist (iLA, NovaLung GmbH, Talheim, Germany). This device does not employ a pump in the circuit. Cannulae are inserted in the femoral artery and vein, and blood flow is driven across the device by the arterial-venous pressure difference.

Extracorporeal lung support was conducted in four ICUs. Three (50\%) patients were transferred from one ICU to another to facilitate ECLS. One-half of the ICUs had formal ECLS protocols specifying inclusion/exclusion criteria as well as initiation and monitoring of laboratory and hemodynamic factors. In one-half of the ICUs, a bedside perfusionist was present at all times. In the other half, ECLS was managed by the ICU team with perfusionist support. Additional staffing was required in two ICUs, although there were no bed closures to facilitate ECLS. There were formal targets for platelet levels (median threshold for transfusion $80 \times 10^{3} \cdot \mathrm{mL}^{-1}[80-120]$ ) 
Table 1 Clinical

Characteristics of H1N1-2009

patients who received ECLS as

compared to the entire cohort of

168 patients as previously

reported $^{10}$
Data are presented as mean

(SD) or median [IQR] unless indicated otherwise

Abbreviations:

ECLS $=$ Extracorporeal Lung

Support; BMI = Body Mass

Index; APACHE = Acute

Physiology and Chronic Health

Evaluation II Score;

$\mathrm{HFOV}=$ High Frequency

Oscillatory Ventilation;

PEEP $=$ Positive End

Expiratory Pressure;

$\mathrm{AST}=$ aspartate

aminotransferase

\begin{tabular}{|c|c|c|}
\hline Patient Characteristics at Baseline & ECLS Patients & All Patients ${ }^{10}$ \\
\hline Confirmed cases, $\mathrm{n}$ & 6 & 168 \\
\hline Age (years) & $22(15.5)$ & $32.3(21.4)$ \\
\hline Sex (female), n (\%) & $5(83 \%)$ & $113(67.3 \%)$ \\
\hline BMI $\left(\mathrm{kg} / \mathrm{m}^{2}\right)$ & $32.6(7.4)$ & $34.6(11)$ \\
\hline First Nations/Inuit/Aboriginal, n (\%) & $2(33)$ & $43(25.6)$ \\
\hline APACHE II Score & $25(3)$ & $19.7(8.7)$ \\
\hline \multicolumn{3}{|l|}{ Time Course of Illness (days) } \\
\hline From Symptoms to Hospital Admission & $6[2-6]$ & $4[2-7]$ \\
\hline From Hospital to ICU Admission & $0.5[0-2.5]$ & $1[0-2]$ \\
\hline From Hospital Admission to ECLS & $5[2.5-8.3]$ & - \\
\hline From ICU Admission to ECLS & $4.5[3.3-8]$ & - \\
\hline \multicolumn{3}{|l|}{ Oxygenation at ICU Admission } \\
\hline Set PEEP $\left(\mathrm{cm} \mathrm{H}_{2} \mathrm{O}\right)$ & $15(9)$ & $9.8(4.0)$ \\
\hline $\mathrm{FiO}_{2}$ & $0.85(0.20)$ & $0.74(0.26)$ \\
\hline $\mathrm{PaO}_{2}(\mathrm{~mm} \mathrm{Hg})$ & $69(12)$ & $95(57)$ \\
\hline $\mathrm{PaO}_{2} / \mathrm{FiO}_{2}(\mathrm{~mm} \mathrm{Hg})$ & $83[11]$ & $147[128]$ \\
\hline \multicolumn{3}{|l|}{ Organ Dysfunction at ICU Admission } \\
\hline Creatinine $(\mathrm{mmol} / \mathrm{L})$ & 65 [64-76] & $65[44-102]$ \\
\hline AST (units/L) & $86[86-153]$ & $64[37-126]$ \\
\hline White Blood Cells (total $/ \mathrm{mm}^{3}$ ) & $6.8(6.5)$ & $9.4(10.0)$ \\
\hline Platelets $\left(\times 10^{3} / \mathrm{ml}\right)$ & $115(129)$ & $189(87)$ \\
\hline Bilirubin (mg/dL) & $22[4-23]$ & $7[4-14]$ \\
\hline Creatine Kinase (units/L) & $361[250-641]$ & 243 [99-922] \\
\hline \multicolumn{3}{|l|}{ Pulmonary Support at ICU Admission } \\
\hline HFOV N (\%) & $3(50 \%)$ & $20(11.9 \%)$ \\
\hline Nitric Oxide N (\%) & $6(100 \%)$ & $23(13.7 \%)$ \\
\hline Prone Ventilation N (\%) & $2(33 \%)$ & $5(3 \%)$ \\
\hline Corticosteroids $\mathrm{N}(\%)$ & $2(33 \%)$ & $85(50.6 \%)$ \\
\hline Neuromuscular Blockade $>24 \mathrm{~h} \mathrm{~N}(\%)$ & $6(100 \%)$ & $47(30 \%)$ \\
\hline
\end{tabular}

in $75 \%$ of the ICUs; the fibrinogen target was $1-2 \mathrm{~g} \cdot \mathrm{L}^{-1}$ in three ICUs. While on ECLS, a mean of 7.5 (6.3 - 13) units of red blood cells, only two $(0-4)$ units of frozen plasma, and one (1 - 3) unit of platelets were transfused per patient (Table 2).

Three patients were supported with HFOV before initiation of ECLS, and one patient was maintained on this mode of ventilation after initiation of ECLS. One-half of the patients required inotropic support while on ECLS, although the use of nitric oxide diminished in frequency. The $\mathrm{F}_{1} \mathrm{O}_{2}$ delivered by the ventilator was decreased after initiation of ECLS, as was peak airway pressure and positive end expiratory pressure (PEEP). These settings are summarized in Table 3.

\section{Liberation from ECLS}

Over the course of ECLS treatment, there was an improvement in $\mathrm{PaO}_{2} / \mathrm{F}_{1} \mathrm{O}_{2}$ ratio and a reduction in $\mathrm{PaCO}_{2}$ (Figure 1). Determination of readiness for liberation from
ECLS was achieved through a variable combination of assessments for satisfactory negative fluid balance and reduction in the level of supplementary oxygen and ventilatory support (for example, PEEP threshold 12 [range 10-14]; $\mathrm{F}_{1} \mathrm{O}_{2}$ threshold 0.50 [range 0.50-0.60]; $\mathrm{PCO}_{2}$ threshold 60 [range 54-70]). Trials of weaning were performed by reducing $\mathrm{F}_{1} \mathrm{O}_{2}$ and extracorporeal flow rates. It is difficult to manipulate blood flow for weaning the iLA, so trials of weaning were performed by reducing the gas (sweep) flow.

\section{Complications}

There were six oxygenator/membrane exchanges in four patients, all due to clotting of various circuit components. Four exchanges occurred in the two patients supported with iLA, the remaining two were in the patients on vv-ECMO. Three patients had cannula or flow difficulties at various times. Significant air in the oxygenator was discovered in one patient. Pulmonary hemorrhage occurred in one 
Table 2 ECLS patient characteristics

\begin{tabular}{ll}
\hline Patient Characteristics & \\
\hline Duration from intubation to start & $5(2.5-8.3)$ \\
$\quad$ ECLS (d) & $15(14-15)$ \\
Duration on ECLS (d) & $17(13.5-20.5)$ \\
Time from end ECLS to extubation (d) & $4(66 \%)$ \\
Pts who had barotrauma before ECLS (n) & $2(33 \%)^{*}$ \\
Pts who had cardiac arrest (n) & $28.3(10.5-33.6)$ \\
Duration of FiO ${ }_{2}=1.0$ before ECLS (h) & $4(67 \%)$ \\
v-vECMO (n) & $2(33 \%)$ \\
ILA (Novalung) (n) & $7.5[6.3-13]$ \\
RBC transfused (units) & $2[0-4]$ \\
FFP transfused (units) & $1[1-3]$ \\
Platelets (adult units)
\end{tabular}

Data are presented as mean (SD) or median [IQR]. * Both cardiac arrests occurred during the period of conventional support prior to initiation of ECLS

Abbreviations: ECLS $=$ Extracorporeal Lung Support; ILA $=$ Interventional Lung Assist; RBC $=$ Red Blood Cells; FFP $=$ Fresh Frozen Plasma (1 unit = approximately $250 \mathrm{ml}$; platelets -1 adult unit $=5$ pooled random donor platelet units) patient, and hemothorax occurred in another patient; both required adjustment of the anticoagulation level. Venous thromboembolism occurred in one patient, and one patient who was supported with vv-ECMO developed heparininduced thrombocytopenia and was reassigned to a nonheparin coated circuit. Bacteremia occurred in three patients. Although there was no commonly employed protocol for monitoring for hemolysis and liver dysfunction, hyperbilirubinemia and increased liver enzymes occurred in three patients. Two patients received renal replacement therapy. Four patients developed pneumothoraces, three while on ECLS with one requiring a thoracostomy tube for bronchopleural fistula management.

\section{Outcomes}

Four patients were successfully liberated from ECLS with acceptable gas exchange and hemodynamics $48 \mathrm{hr}$ after liberation. However these patients required an additional 17 (13.5-20.5) days of conventional mechanical ventilation. The total duration of mechanical ventilation, ICU

Table 3 ECLS specific characteristics over the course of ECLS

\begin{tabular}{|c|c|c|c|c|c|}
\hline $\begin{array}{l}\text { Characteristics of } \\
\text { Patients on ECLS* }\end{array}$ & $\begin{array}{l}1 \text { hour before } \\
\text { ECLS start }\end{array}$ & $\begin{array}{l}2 \text { hours after } \\
\text { ECLS start }\end{array}$ & $\begin{array}{l}2 \text { days after } \\
\text { ECLS start }\end{array}$ & $\begin{array}{l}24 \text { hours before } \\
\text { ECLS stop }\end{array}$ & $\begin{array}{l}48 \text { hours after } \\
\text { ECLS stop }\end{array}$ \\
\hline $\mathrm{pH}$ & $7.31(0.05)$ & $7.43(0.06)$ & $7.40(0.06)$ & $7.41(0.06)$ & $7.39(0.07)$ \\
\hline $\mathrm{PaO}_{2}(\mathrm{~mm} \mathrm{Hg})$ & $58(17)$ & $57(14)$ & $66(12)$ & $105(45)$ & $77(16)$ \\
\hline $\mathrm{SaO}_{2}(\%)$ & $86(7)$ & $89(4)$ & $92(4)$ & $96(4.5)$ & $94(5)$ \\
\hline $\mathrm{SvO}_{2}(\%)$ & $85(7)$ & $89(2)$ & $87(4)$ & $83(12)$ & $93(0)^{*}$ \\
\hline $\mathrm{FiO}_{2}$ & $1[1-1]$ & $0.68[0.25]$ & $0.68[0.26]$ & $0.59[0.22]$ & $0.42[0.06]$ \\
\hline $\operatorname{PEEP}\left(\mathrm{cm} \mathrm{H}_{2} \mathrm{O}\right)$ & $20(0)$ & $15(4)$ & $15(6)$ & $14(6.4)$ & $10(2.8)$ \\
\hline Ppeak $\left(\mathrm{cm} \mathrm{H}_{2} \mathrm{O}\right)$ & $44(42)$ & $34(4)$ & $31(3)$ & $34(14)$ & $27(3)$ \\
\hline \multicolumn{6}{|l|}{ Ventilation Mode } \\
\hline Assist-control (pressure) & $1(17 \%)$ & $3(59 \%)$ & $4(67 \%)$ & $1(17 \%)$ & $2(40 \%)$ \\
\hline Assist-control (volume) & $2(33 \%)$ & $1(17 \%)$ & - & $3(50 \%)$ & - \\
\hline Pressure Support & - & - & $1(17 \%)$ & $1(17 \%)$ & $3(60 \%)$ \\
\hline HFOV & $3(50 \%)$ & $1(17 \%)$ & $1(17 \%)$ & - & - \\
\hline APRV & - & - & - & $1(17 \%)$ & - \\
\hline Nitric Oxide, N (\%) & $4(67 \%)$ & $4(67 \%)$ & $3(50 \%)$ & $2(33 \%)$ & $0(0 \%)$ \\
\hline Neuromuscular blockade, N (\%) & $5(83 \%)$ & $6(100 \%)$ & $6(100 \%)$ & $3(50 \%)$ & $0(0 \%)$ \\
\hline Inotrope, $\mathrm{N}(\%)$ & $2(33 \%)$ & $3(50 \%)$ & $3(50 \%)$ & $3(50 \%)$ & $1(20 \%)$ \\
\hline MAP (mmHg) & $83(16)$ & $87(16)$ & $87(18)$ & $76(22)$ & $82(19)$ \\
\hline HR (beats/minute) & $96(30)$ & $99(26)$ & $100(14)$ & $105(18)$ & $116(19)$ \\
\hline Cumulative fluid balance (ml) & - & $-185[-703-491]$ & $105[-2007-1912]$ & $1338[-694-2680]$ & $-48[-1008-1144]$ \\
\hline RASS & $-5[-5--5]$ & $-5[-5--5]$ & $-5[-5--3]$ & $-4[-4--2]$ & $-2[-3--1]$ \\
\hline Lactate $(\mathrm{mmol} / \mathrm{L})$ & $1.3(0.2)$ & $1.9(0.6)$ & $1.5(0.3)$ & $1.2(0.6)$ & $1.1(0.4)$ \\
\hline Platelets $\left(\mathrm{x} 10^{3} / \mathrm{mL}\right)$ & 167 [139-224] & $350[301-372]$ & 143 [128-300] & $145[131$ to 168$]$ & 159 [136-190] \\
\hline $\mathrm{ACT}(\mathrm{sec})$ & $78(104)$ & $213(65)$ & $164(328)$ & $197(50)$ & - \\
\hline
\end{tabular}

* APRV = Airway Pressure Release Ventilation; ACT = Activated Clotting Time; RASS = Richmond Agitation Sedation Score; MAP = Mean Arterial Pressure; HR = Heart Rate; HFOV = High Frequency Oscillatory Ventilation; PEEP = Positive End Expiratory Pressure; Ppeak = Peak Airway Pressure; data are means (SD) or median [IQR] unless indicated otherwise 


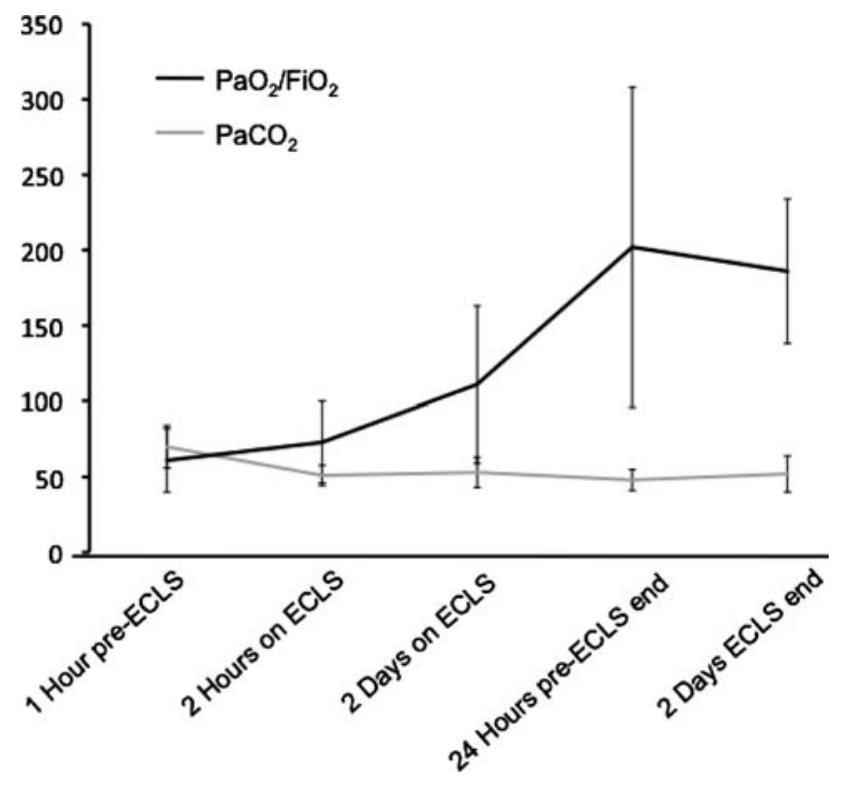

Fig. $1 \mathrm{PaO}_{2} / \mathrm{F}_{1} \mathrm{O}_{2}$ ratio and $\mathrm{PaCO}_{2}(\mathrm{mmHg})$ over the time course of extracorporeal lung support (ECLS)

Table 4 Outcomes of ECLS patients compared to the entire cohort ${ }^{10}$

\begin{tabular}{|c|c|c|}
\hline Outcomes & $\begin{array}{l}\text { ECLS } \\
(\mathrm{n}=6)\end{array}$ & $\begin{array}{l}\text { All patients } \\
(\mathrm{n}=168)^{10}\end{array}$ \\
\hline $\begin{array}{l}\text { Mortality at } 28 \text { days } \\
\text { from ICU Admission (n) }\end{array}$ & $2(33 \%)$ & $24(14.3 \%)$ \\
\hline Duration of Ventilation (d) & $26.5[18-40.3]$ & $12[6-20]$ \\
\hline From Hospitalization to Death (d) & $18[15-21]$ & $14[6-20]$ \\
\hline Length of ICU stay (d) & $28[18.5-37.5]$ & $12[5-20]$ \\
\hline
\end{tabular}

Data are presented as median [IQR] unless otherwise indicated

length of stay, and hospital length of stay was longer in the ECLS group than in the non-ECLS group. Two ECLS patients died (33\% mortality vs $17.3 \%$ for the whole cohort) of multisystem organ failure while on ECLS. The first patient who was $17 \mathrm{yr}$ of age died after 21 days of ventilation and 15 days of ECLS; the second patient was $51 \mathrm{yr}$ of age and died after 16 days of ventilation and 14 days of ECLS. These outcomes are summarized in Table 4.

\section{Discussion}

Six of the 168 patients who had confirmed H1N1-2009 infection in Canada were deemed to be unresponsive to conventional therapeutic interventions and were treated with ECLS. Four of these patients were successfully liberated from ECLS and survived their critical illness. Notably, this outbreak disproportionately affected young females, Aboriginal patients, and those who did not have major pre-existing comorbidities.

At present, ECLS for ARDS is generally considered as an alternative treatment in adults with ARDS who are unresponsive to other forms of support. At present, there is no consensus on absolute indications or contra-indications to ECMO or iLA. Initiation guidelines vary among centres and are based mostly on personal and institutional experience. As the H1N1-2009 pandemic evolved, however, ECLS teams received requests for this therapy. The many uncertain aspects of the pandemic further clouded the decision-making process. Specifically, the course of the disease was uncertain, as was the number of potentially affected individuals. Nonetheless, as more patients developed ARDS due to H1N1-2009 infection, it became clear that an attempt at ECLS would be required in some young, otherwise healthy individuals.

The greatest benefit of ECMO is expected to occur when initiated early in the course of severe lung injury before the evolution of increasing multisystem disease. However, it is challenging to identify patients who will not respond to more conventional therapies. Numerous studies have shown that ECMO is not beneficial and may be associated with increased mortality if offered to all patients who have ARDS according to the consensus criteria. ${ }^{20}$ In 1979, the first randomized trial comparing ECMO with conventional ventilation for treatment of ARDS reported a survival rate of $<10 \%$ in both groups and no significant difference in mortality. ${ }^{21}$ However, there has been recent interest in nonrandomized studies supporting the use of ECMO in adults who have severe hypoxic respiratory failure. ${ }^{22}$

Most recently, the Conventional Ventilation or ECMO for Severe Adult Respiratory Failure (CESAR) trial compared ARDS treatment with or without ECMO in patients who had very severe ARDS. In this study, 180 patients were prospectively randomized to treatment in centres that deliver ECMO or to treatment in centres that deliver conventional ventilation. ${ }^{19}$ While the investigators were able to demonstrate an improvement in the composite outcome of death/cognitive dysfunction in favour of ECMO, there was no difference in all-cause mortality. ${ }^{23}$ Furthermore, although these were patients with severe ARDS, ECMO was not the sole therapy in that treatment arm. With proper patient selection, the mortality among patients who have the most severely impaired gas exchange treated with ECMO can be lowered to approximate the mortality of those patients not requiring ECMO. ${ }^{24-28}$ The Australia and New Zealand (ANZ) influenza investigators recently reported their experience with ECMO for respiratory failure secondary to H1N1-2009 infection in ANZ. ${ }^{29}$ In this series, ECMO usage for H1N1-2009 infection was frequent $(68 / 201,33.8 \%)$, whereas it was infrequent in Canada $(6 / 168,3.6 \%)$. The time from intubation to initiation of 
ECLS in ANZ was also shorter, i.e., mean two days vs mean five days in our series, although gas exchange parameters immediately prior to the initiation of ECLS were similar. The sole method of ECLS used in the ANZ series was vv-ECMO. Survival rates in both series were similar.

While ECMO has been in use in Canada for over $20 \mathrm{yr}$, the Novalung iLA is a new device to Canada, approved in 2008, and has been used in very few centres. Proposed as an alternative to the full ECMO, the pumpless iLA circuit has demonstrated benefit in severe hypoxemic lung failure $\left(\mathrm{PaO}_{2} / \mathrm{F}_{\mathrm{I}} \mathrm{O}_{2}\right.$ ratio $<65$ despite optimized ventilator settings). ${ }^{30}$ Although this device is most beneficial for carbon dioxide removal, it may also improve oxygenation. The indications for iLA have therefore been extended by some to include the prevention of ventilator-associated lung injury during the early phase of ARDS. ${ }^{13}$ This concept recognizes the inability to limit plateau pressures and tidal volumes in a situation of grossly diminished respiratory compliance without causing severe hypercapnia and profound respiratory acidosis. However, there are no published clinical trials regarding this device. The Canadian critically ill H1N1 patients were characterized by a hyperacute disease process and rapid deterioration, often within hours of hospital admission. Our limited experience of iLA for H1N1-infection cannot determine whether this treatment is effective. The results from a multicentre trial (XTRAVENT, Clinical.Trials.Gov. identifier NCT00538928) may provide further insight into the utility of this therapy. As such, iLA therapy should be considered experimental at the present time, and treatment should be offered in the context of clinical investigation.

Traditionally, the conduct of ECMO has required constant attention from a perfusionist who is present at the bedside. In our series, only one-half of the ICUs mandated "in-house" coverage by perfusion staff. The rationale for mandating constant attendance by perfusion staff was to deal with the unlikely scenario of a circuit catastrophe, such as inadvertent decannulation, air embolism, or clotting of the circuit. Circuit complications were quite frequent in our series (four of six patients required circuit/ oxygenator exchange), including two patients where ECMO specialists did not constantly supervise ECLS. Despite the practices that we observed, the general consensus is that ECLS specialists should remain in the hospital when a patient is undergoing ECLS. ${ }^{22}$

In conclusion, the use of ECLS in the setting of H1N12009 infection is feasible and may be effective in certain centres. The use of ECMO and perhaps iLA may support gas exchange and prevent on-going lung injury and mortality in patients who have severe injury that is refractory to other interventions. However, this treatment is associated with a high incidence of serious complications. Therefore, jurisdictions should develop guidelines for consideration of this therapy for the expected autumn and winter wave of influenza A (H1N1) 2009.

Acknowledgements CCCTG H1N1 Collaborative:

Nova Scotia: Halifax (Dietrich Henzler, Richard Hall, Rob Greene, Lisa Julien, Debra Wright, Queen Elizabeth II Health Sciences Centre)

Québec: Québec City (François Lauzier, Alexis Turgeon, Caroline Roy, CHA-Hôpital de l'Enfant-Jésus; François Lellouche, MarieClaude Ferland, Institut universitaire de cardiologie et de pneumologie de Québec), Longueuil (Germain Poirier, Hôpital Charles-LeMoyne), Sherbrooke (François Lamontagne, Centre Hospitalier universaire de Sherbrooke [CHUS]), Montreal (Phillippe Jouvet, Jacques Lacroix, CHU Sainte-Justine; Kosar Khwaja, Denny Laporta, David Hornstein, Laura Banici SMBD-Jewish General Hospital, McGill University; Stéphane P. Ahern, Yoanna Skrobic, Johanne Harvey, Hôpital Maisonneuve Rosemont; Martin Albert, Isabelle Arsenault, Hôpital du Sacré-Coeur de Montréal)

Ontario: Ottawa (Lauralyn McIntyre, Claude Gaudet, Ray Saginur, Joe Pagliarello, Irene Watpool, Tracy Mcardle, Ottawa Hospital; Kusum Menon, Dermot Doherty, Sonny Dhanani, Roxanne Ward, Children's Hospital of Eastern Ontario); Kingston (John Muscedere, Nicole Godfrey, Kingston General Hospital); Toronto (Robert Fowler, Ruxandra Pinto, Neill Adhikari, Sunnybrook Hospital; Stephen Lapinsky, Cheryl Ethier, Tom Stewart, Mount Sinai Hospital; Orla Smith, John Marshall, Jan Friedrich, Karen Burns, Jan Friedrich, St. Michael's Hospital; Jeffrey M. Singh, John Granton, Nancy Brockest, Niall Ferguson, Andrea Matte, University Health Network; Jamie Hutchison, Hospital for Sick Children; Rob Cirone, St. Joseph's Health Centre); Hamilton (Deborah Cook, Ellen MacDonald, Kelly Wilton, Andrea Tkaczyk, St. Joseph's Healthcare; Karen Choong, Mark Duffett, McMaster University Children's Hospital; Maureen Meade Hamilton Health Sciences Centre, General Site, Andy Freitag, Hamilton Health Sciences Centre, McMaster Site; Tim Karachi, Hamilton Health Sciences Centre, Henderson Site); Guelph (Gerry Hollinger, Guelph General Hospital); London (Claudio Martin, London Health Sciences Centre); Windsor (Eli Malus, Maureen Hrytsyk, Hotel Dieu Grace Hospital)

Manitoba: Winnipeg (Anand Kumar, Ryan Zarychanski, Faisal Siddiqui, Duane Funk, Allan Garland, Wendy Janz, Nicole Marten, Kim Wiebe, Mandy Siddiqui, Clare Ramsey, Satendra Sharma, Kendiss Olafson, Health Sciences Centre/St. Boniface Hospital/Grace Hospital/Victoria Hospital/Concordia Hospital/Seven Oaks Hospital); Brandon (Charles Penner, Brandon Regional Health Authority).

Alberta: Calgary (Tom Stelfox, Foothills Medical Centre); Edmonton (Sean M. Bagshaw, University of Alberta Hospital, Mark Heule, Misericordia Hospital; Curtis Johnston, Royal Alexandria Hospital, Marcia Johnson, Public Health Division, Alberta Health Services, Sean Norris, Sturgeon Hospital, Ari Joffe, Stollery Children's Hospital)

British Columbia: Vancouver (Peter Dodek, St. Paul's Hospital; Peter Skippen, BC Children's Hospital; Donald E. G. Griesdale, Denise Foster, Vancouver General Hospital); New Westminster (Sean Keenan, Steven Reynolds).

Sources of funding None.

Conflict of interest and financial disclosure None declared.

\section{References}

1. Centers for Disease Control and Prevention (CDC). Outbreak of swine-origin influenza A (H1N1) virus infection - Mexico, MarchApril 2009. MMWR Morb Mortal Wkly Rep 2009; 58: 467-70. 
2. World Health Organization Situation Updates - Pandemic (H1N1) 2009 - update 65, 11 September 2009. Available from URL: http://www.who.int/csr/don/2009_09_11/en/index.html (accessed September 2009).

3. Cutler J, Schleihauf E, Hatchette TF, et al. Investigation of the first cases of human-to-human infection with the new swine-origin influenza A (H1N1) virus in Canada. CMAJ 2009; 181: 159-63.

4. Public Health Agency of Canada Deaths associated with H1N1 flu virus in Canada. Available from URL: http://www.phac-aspc. gc.ca/alert-alerte/h1n1/surveillance-eng.php (accessed September 2009).

5. Public Health Agency of Canada. Cases of H1N1 flu virus in Canada. Available from URL: http://www.phac-aspc.gc.ca/ alert-alerte/h1n1/surveillance-archive/20090715-eng.php (accessed September 2009).

6. Kermode-Scott B. Canada has world's highest rate of confirmed cases of A/H1N1, with Aboriginal people hardest hit. BMJ 2009; 339: b2746.

7. Anonymous. Human infection with new influenza A (H1N1) virus: clinical observations from Mexico and other affected countries, May 2009. Wkly Epidemiol Rec 2009; 84: 185-9.

8. Dawood FS, Jain S, Finelli L, et al. Emergence of a novel swineorigin influenza A (H1N1) virus in humans. N Engl J Med 2009; 360: 2605-15.

9. Centers for Disease Control and Prevention $(C D C)$. Hospitalized patients with novel influenza A (H1N1) virus infection California, April-May, 2009. MMWR Morb Mortal Wkly Rep 2009; 58: 536-41.

10. Kumar A, Zarychanski R, Pinto $R$, et al. Critically ill patients with 2009 influenza A(H1N1) infection in Canada. JAMA 2009; 302: 1872-9.

11. Perez-Padilla R, de la Rosa-Zamboni D, Ponce de Leon S, et al. Pneumonia and respiratory failure from swine-origin influenza $A$ (H1N1) in Mexico. N Engl J Med 2009; 361: 680-9.

12. Lewandowski K, Weimann J. Can lung protective ventilation methods modify outcome?-A critical review (German). Anaesthesiol Reanim 2002; 27: 124-30.

13. Zimmermann $M$, Bein $T$, Arlt $M$, et al. Pumpless extracorporeal interventional lung assist in patients with acute respiratory distress syndrome: a prospective pilot study. Crit Care 2009; 13: R10.

14. Public Health Agency of Canada. Case Definitions for National Surveillance H1N1 Flu Virus. Available from URL: http://www. phac-aspc.gc.ca/alert-alerte/swine-porcine/hp-ps-info_definitioneng.php (accessed July 2009)

15. Canadian Critical Care Trials Group. Case Report Form. Available from URL: http://www.ccctg.ca/news_events.php (accessed July 2009).

16. Knaus WA, Draper EA, Wagner DP, Zimmerman JE. APACHE II: a severity of disease classification system. Crit Care Med 1985; 13: 818-29.
17. Pollack MM, Patel KM, Ruttimann UE. PRISM III: an updated Pediatric Risk of Mortality score. Crit Care Med 1996; 24: $743-$ 52.

18. Lee N, Chan PK, Hui DS, et al. Viral loads and duration of viral shedding in adult patients hospitalized with influenza. J Infect Dis 2009; 200: 492-500.

19. Peek GJ, Clemens F, Elbourne D, et al. CESAR: conventional ventilatory support vs extracorporeal membrane oxygenation for severe adult respiratory failure. BMC Health Serv Res 2006; 6: 163.

20. Morris AH, Wallace CJ, Menlove RL, et al. Randomized clinical trial of pressure-controlled inverse ratio ventilation and extracorporeal $\mathrm{CO} 2$ removal for adult respiratory distress syndrome. Am J Respir Crit Care Med 1994; 149: 295-305.

21. Zapol WM, Snider MT, Hill JD, et al. Extracorporeal membrane oxygenation in severe acute respiratory failure. A randomized prospective study. JAMA 1979; 242: 2193-6.

22. Schuerer DJ, Kolovos NS, Boyd KV, Coopersmith CM. Extracorporeal membrane oxygenation: current clinical practice, coding, and reimbursement. Chest 2008; 134: 179-84.

23. Peek GJ, Mugford M, Tiruvoipati R, et al. Efficacy and economic assessment of conventional ventilatory support versus extracorporeal membrane oxygenation for severe adult respiratory failure (CESAR): a multicentre randomised controlled trial. Lancet 2009; 374: 1351-63.

24. Linden $V$, Palmer $K$, Reinhard $J$, et al. High survival in adult patients with acute respiratory distress syndrome treated by extracorporeal membrane oxygenation, minimal sedation, and pressure supported ventilation. Intensive Care Med 2000; 26: 1630-7.

25. Henzler D, Dembinski $R$, Kopp $R$, Hawickhorst $R$, Rossaint $R$, Kuhlen $R$. Treatment of acute respiratory distress syndrome in a treatment center. Success is dependent on risk factors (German). Anaesthesist 2004; 53: 235-43.

26. Bartlett RH. Extracorporeal life support in the management of severe respiratory failure. Clin Chest Med 2000; 21: 555-61.

27. Bartlett RH, Roloff DW, Custer JR, Younger JG, Hirschl RB. Extracorporeal life support: the University of Michigan experience. JAMA 2000; 283: 904-8.

28. Mols G, Loop T, Geiger K, Farthmann E, Benzing A. Extracorporeal membrane oxygenation: a ten-year experience. Am J Surg 2000; 180: 144-54.

29. Australia and New Zealand Extracorporeal Membrane Oxygenation (ANZ ECMO) Influenza Investigators, Davies A, Jones D, Bailey M, et al. Extracorporeal Membrane Oxygenation for 2009 Influenza A(H1N1) Acute Respiratory Distress Syndrome. JAMA 2009; 302: 1888-95.

30. Bein T, Weber F, Philipp A, et al. A new pumpless extracorporeal interventional lung assist in critical hypoxemia/hypercapnia. Crit Care Med 2006; 34: 1372-7. 